\section{Sir Ronald Baskett}

Sir Ronald BasketT, who died on November 24, worked for almost the whole of his career in agricultural education and research. After graduation from Reading his appointment in 1924 as assistant to the Head of the Chemical and Animal Nutrition Division of the Ministry of Agriculture for Northern Ireland afforded him an opportunity to extend one of his important interests, namely, the application of the techniques of analytical chemistry to the study of the composition and nutritive value of foods for man and livestock. At Queen's University, Belfast, where he worked until 1959, he took part in early investigations of mineral metabolism of farm animals and on the quality of products such as bacon and eggs. This was at a time when agriculture in the province was becoming aware of the value of producer organizations in the marketing of produce and in the maintenance of quality so important to exporters to the mainland. Though at this time, and indeed subsequently in his career, he did not have much time to devote to his own research because of heavy administrative duties, Baskett succeeded in building up an enthusiastic group of research workers at Queen's which made considerable contributions to knowledge of the nutrition of pigs and poultry and the utilization of forage crops and the interest in these topics is still maintained in the Agricultural Chemistry Department.

He was appointed Head of the Chemical and Animal Nutrition Division in 1928 and Professor of Agricultural Chemistry at Queen's in 1935, helping in building up the Faculty of Agriculture and later acting as Dean for a considerable period. He had a great interest in course structures in agricultural science teaching and served as a member of the Inter-University Council for Higher Education in the Colonies. In 1950 he left Belfast to spend a two-year period as Agricultural Attaché to the British Embassy in Washington, returning to become Permanent Secretary to the Ministry of Agriculture in Northern Ireland, but he only remained in the post for a short period, returning to the University as Professor and the post of Chief Scientific Officer in the Ministry which he had held since 1947.

Baskett's long experience of university and government administration in science was of great value to him in 1959 when he undertook the onerous task of Director of the National Institute for Research in Dairying. Here he contributed greatly to the development of closer links between the University of Reading and the Institute. He recognized the value of these links in the applied sciences associated with agriculture. At Reading he took a particular interest in areas of research of immediate benefit to the dairy industry such as the development of husbandry procedures for the control of mastitis.

In addition to his day-to-day management of the Institute, Baskett also served on many committees, for example on milk composition and on the veterinary profession. He was Chairman of the ARC Working Party on the Nutrient Requirements of Pigs which published a report incorporating new recommended feeding standards for this animal in 1967.

He retired from the Directorship of the National Institute for Research in
Dairying in 1967 and returned to live in Northern Ireland. It was a measure of his dedication to agricuitural research that even after his retirement he was persuaded to undertake the Secretaryship of the ARC as a short-term appointment in 1971. During his year of office he took care of the negotiations between the Council and the Government Departments on science research policy and this work contributed greatly to the development of future arrangements for research management in this field.

He was awarded the OBE in 1947, received an Hon DSc from Queen's University, Belfast, in 1963, and was knighted in 1966.

$\mathrm{He}$ is survived by his wife and three sons.

\section{Errata}

Paragraph five of the News and Views article "Age and Cancer Incidence" (Nature, 241, 238; 1973) described experiments in which tissue transplanted from cancer-susceptible animals into various hosts was found still to be cancer-susceptible when, long after the original operation, a carcinogen was applied to the transplant. Conversely, cancer-resistant tissue remained cancer-resistant even when transplanted into a cancer-susceptible animal. Unfortunately, the News and Views article inadvertently stated the opposite of this result.

IN the article "Terrestrial Heat Flow, the Neutrino Problem, and a Possible Energy Source in the Core", by V. M. Hamza and A. E. Beck (Nature, 240, $343 ; 1972)$ the last figure in column 7 of Table 1 should be 0.71 , and not 0.11 .

\section{HOW TO BUY NATURE}

The cost of one year's subscription to NATURE is:

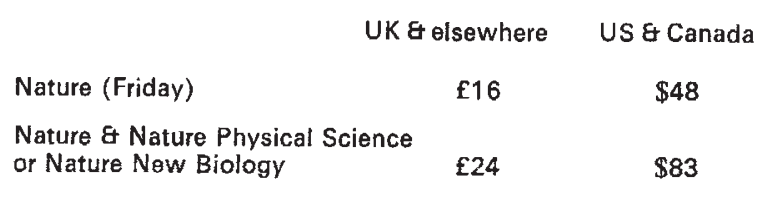

Nature New Biology or Nature

Physical Science

All three editions

$£ 29.50$

$\$ 108$

(Charges for delivery by air mail on application). Subscribers in North America may be able to claim a tax rebate against their NATURE subscription.
Editorial, Advertising and Publishing Offices of NATURE

MACMILLAN JOURNALS LIMITED

4 LITTLE ESSEX STREET, LONDON WC2R 3LF Telephone Number: 01-836 6633. Telegrams: Phusis London WC2R 3LF

MACMILLAN JOURNALS LIMITED

711 NATIONAL PRESS BUILDING

WASHINGTON DC 20004

Telephone Number : 202-737 2355. Tolex 64280

International Advertisement Manager

PETER R. KAVANAGH

MACMILLAN JOURNALS LIMITED

4 LITTLE ESSEX STREET, LONDON WC2R 3LF

Telephone Numbers: UK 01-836 6633. USA 202-737 2355

Subscription Department

MACMILLAN JOURNALS LIMITED

BRUNEL ROAD, BASINGSTOKE, HANTS RG21 2XS

Telephone Number: Basingstoke 29242

Classified advertisements

T. G SCOTT \& SON, LIMITED

1 CLEMENT'S INN, LONDON WC2A 2ED

Telephone Number : $01-242$ 6264/01-405 4743

Telegrams : Textualist London WC2A 2ED

Registered as a newspaper at the Post Office

Copyright (C) Macmillan Journais Limited, February 161973 